\title{
Efektifitas Fraksi Kromotografi Ekstrak Buah Pare terhadap Peningkatan Bobot Badan Tikus pada Kondisi Diabetes Mellitus
}

\section{(EFFECTIVENESS OF CHROMOTOGRAPHY FRACTION OF MOMORDICA CHARANTIA ON INCREASE OF RAT BODY WEIGHT WITH DIABETES MELLITUS)}

\section{Cyrilus Jefferson Bour $^{1 *}$, I Nyoman Suartha ${ }^{2}$, Luh Made Sudimartini ${ }^{3}$}

\author{
${ }^{1}$ PT Indotirta Suaka, JL. Culindo Lestari, Blok. B 3-4, Tiban Indah, Kec. Sekupang, Kota \\ Batam, Kepulauan Riau, Indonesia, 29424; \\ ${ }^{2}$ Laboratorium Diagnosa Klinik Veteriner, Fakultas Kedokteran Hewan, Universitas \\ Udayana, Jl. PB. Sudirman Denpasar Bali, Indonesia 80225; \\ ${ }^{3}$ Laboratorium Farmasi Veteriner, Fakultas Kedokteran Hewan, Universitas Udayana, Jl. PB. \\ Sudirman Denpasar Bali, Indonesia 80225. \\ *Email: bourjefferson@yahoo.co.id
}

\begin{abstract}
ABSTRAK
Tujuan dari penelitian ini untuk melihat pengaruh pemberian fraksi kromotografi ekstrak buah pare terhadap peningkatan bobot badan tikus putih jantan yang menderita diabetes mellitus. Buah pare diekstrasi menggunakan etanol $70 \%$, kemudian dipartisi dengan N-Heksan, dan dilanjutkan dengan kromotografi lapis tipis, sehingga diperoleh lima fraksi. Sebanyak 40 ekor tikus putih jantan (Rattus novergicus) umur 3-4 bulan dengan bobot badan 150-200 g dan diadaptasikan selama dua minggu, dikelompokkan menjadi delapan kelompok perlakuan dengan masing-masing kelompok terdiri dari lima ekor. Setiap perlakuan diperiksa kadar glukosa darah serta rata-rata bobot badan tikus pada hari ke -1, 0 (tikus hiperglikemia), 4, 11, dan 18. Kondisi diabetes mellitus pada setiap kelompok kecuali kontrol negatif dibuat dengan menyuntikan larutan streptozotozin (STZ) secara intraperitoneal pada hari ke-0 dengan dosis $45 \mathrm{mg} / \mathrm{kg}$ bb. Hasil penelitian menunjukkan bahwa pemberian fraksi 1 dan 5 buah pare dosis $50 \mathrm{mg} / \mathrm{kg}$ bb mampu meningkatkan bobot badan secara sangat nyata tikus pada hari ke4. sama seperti pemberian ekstrak etanol buah pare. Fraksi 2, 3 dan 4 buah pare dengan dosis yang sama baru mampu meningkatkan bobot badan secara sangat nyata pada hari ke- 11. Disimpulkan hasil perlakuan menunjukkan bahwa fraksi 1 atau 5 lebih cepat memberikan reaksi peningkatan bobot badan dibandingkan dengan fraksi yang lain.
\end{abstract}

Kata kunci: Momordica charantia; bobot badan; kromotografi.

\begin{abstract}
The purpose of this research is to identify the effects the provision of faction chromatography extract of Momordica charantia on the increase in body weight white male diabetes mellitus rats. Momordica charantia extracted using ethanol 70\%, then partitioned with n-hexan, and continued with thin layer chromatography, to achieve five factions. 40 white male rats (Rattus novergicus) of 3-4month-old with 150-200 g of body weight were adapted for two weeks, arranged to eight the treatment groups which each group consists of 5 rats. Every treatment was checked blood glucose levels and the average of body weight on the day $-1,0$ (hiperglikemia rats), 4, 11, 18. The condition of diabetes mellitus in every group except the negative control that was made by injecting streptozotocin (STZ) on day 0 at a dose of $45 \mathrm{mg} / \mathrm{kg}$. The results of the study showed that the faction 1 and 5 pare fruit doses 50 $\mathrm{mg} / \mathrm{kg}$ bb able to increased high significally weight mice on the day $4^{\text {th }} .$. equal such as extract ethanol of pare fruit. Faction 2, 3 and 4 pieces pare with same dosage are able to increase high significantly weight on the day $11^{\text {th }}$ century. In conclusion, the results showed faction treatment 1 and 5 were faster respond of increasing weight compared with other fractions.
\end{abstract}

Keywords: Momordica charantia; body weigth; chromatography. 


\section{PENDAHULUAN}

Penderita diabetes mellitus (DM) dewasa ini terus meningkat seiring dengan meningkatnya tingkat kemakmuran dan berubahnya gaya hidup (Pasaribu et al., 2012). Diabetes mellitus merupakan suatu penyakit yang melibatkan hormon endokrin pankreas, antara lain insulin dan glucagon (Kendran et al., 2013). Manifestasi utamanya mencakup gangguan metabolisme lipid, karbohidrat, dan protein yang pada gilirannya merangsang kondisi hiperglikemia (Yuliana et al., 2013). Hiperglikemia biasanya terjadi apabila sel $\beta$ dalam pulau Langerhans pankreas tidak dapat menghasilkan insulin (Abeeleh et al., 2009).

Penurunan bobot badan pada penderita DM berkaitan dengan defek sekresi insulin (insulin kurang) dan gangguan kerja insulin (resistensi insulin). Bila insulin tidak disekresikan, glukosa dalam tubuh tidak bisa difasilitasi oleh insulin untuk masuk ke sel dan menghasilkan energi. Untuk memenuhi kebetuhan energi cadangan glukosa di otot maupun hati dibongkar untuk menghasilkan energi melalui proses glikogenolisis dan lipolisis. Apabila kedua proses ini terjadi terus menerus, maka bobot badan menurun akibat massa otot dan jaringan lemak berkurang (Steyn et al., 2004).

Penelitian menggunakan hewan coba telah banyak menghasilkan penemuan mengenai bermacam-macam diagnosa, terapi maupun obat-obat yang digunakan dalam penanganan penyakit diabetes mellitus (Nugroho, 2006). Kondisi DM dapat diinduksi pada hewan coba dengan cara pemberian zat kimia sebagai induktor DM (diabetogen) contohnya Streptozotosin (STZ). Streptozotosin bekerja dengan cara membentuk radikal bebas yang dapat menimbulkan kerusakan pada membral sel, protein, deoxyribo-nucleic acid (DNA), akibatnya terjadi gangguan produksi insulin oleh sel beta Langerhans pankreas (McAnuff et al., 2003).

Pengobatan DM membutuhkan biaya besar dan waktu yang lama. Lamanya pengobatan disebabkan oleh adanya berbagai komplikasi penyakit. Oleh karena itu, dibutuhkan obat yang efektif dengan efek samping yang rendah serta harga yang murah (Bawa, 2009). Penggunaan obat tradisional secara umum dinilai lebih aman dari pada penggunaan obat modern. Salah satu jenis tanaman yang banyak digunakan sebagai obat tradisional adalah pare. Tanaman pare (Momordica charantia L) merupakan salah satu tanaman obat yang terbukti sebagai bahan baku obat yang berkhasiat sebagai antidiabetes (Hernawati, 2009). Buah pare kaya akan vitamin $C$, vitamin $A$, fosfor, dan zat besi yang mampu menangkal radikal bebas pada kasus DM.

Penelitian sebelumnya telah dilakukan kajian terhadap pemberian fraksi N-Heksan buah pare yang mampu menurunkan kadar glukosa darah tikus putih jantan. Diketahui dari hasil uji fitokimia, fraksi 1 merupakan fraksi yang paling cepat menurunkan kadar glukosa darah karena terdekteksi adanya golongan tritepenoid (Suatha et al., 2016). Penelitian pengaruh pemberian fraksi buah pare terhadap peningkatan bobot badan diketahui belum pernah dilakukan. Oleh karena itu, dirasa perlu dilakukanya penelitian tersebut. Penelitian ini bertujuan untuk melihat pengaruh pemberian fraksi buah pare hasil kromotografi lapis tipis dari partisi N-Heksan yang mampu meningkatkan bobot badan tikus putih jantan dalam kondisi DM.

\section{METODE PENELITIAN}

\section{Pembuataan ekstrak buah pare}

Ekstrak buah pare dibuat dengan cara menimbang sebanyak $5 \mathrm{~kg}$ buah pare segar lalu dihancurkan dengan menggunakan mortal, kemudian ditambahkan pelarut etanol $70 \%$ dan dimasukan ke dalam wadah, ditutup dan dibiarkan selama dua hari terlindungi dari cahaya namun sesekali sambil diaduk, kemudian disaring sehingga didapat maserat. Ampas dimaserasi dengan etanol $70 \%$ menggunakan prosedur yang sama, maserasi dilakukan sampai diperoleh maserat yang jernih. Semua maserat etanol digabung dan diuapkan dengan 
menggunakan alat penguap vacum putar pada temperatur $\pm 40^{\circ} \mathrm{C}$ sampai diperoleh ekstrak etanol kental kemudian dikeringkan menggunakan freezer dryer.

\section{Pembuatan partisi N-heksan 2\%}

Partisi N-heksan ditimbang sebanyak 2 g kemudian dilarutkan dengan aquabides hingga mencapai $100 \mathrm{ml}$ dan kemudian dihomogenkan untuk mendapatkan larutan partisi N-heksan $2 \%$.

\section{Kromotografi kolom}

Penggunaan fraksi kromatografi bertujuan untuk memisahkan komponenkomponen di dalam ekstrak hasil partisi agar diperoleh senyawa tunggal. Adapun tahapan kerja kromotografi kolom adalah sebagai berikut:

\section{Pembuatan Bubur Silikagel}

Sekitar 60 Gram silikagel G 60 setelah diaktifkan dengan cara memanaskan di dalam oven $110^{\circ} \mathrm{C}$ selama 2 jam, lalu disuspensikan ke dalam kira-kira $100 \mathrm{~mL}$ pelarut yang akan digunakan sebagai fase gerak, kemudian diaduk sampai menjadi bubur.

\section{Pengisian Kolom}

Kolom kaca dipasang tegak lurus dengan bantuan statif dan klem. Ke dalam kolom dengan posisi keran tertutup tersebut dimasukkan kira-kira $50 \mathrm{~mL}$ fase gerak, kemudian dimasukkan glasswool atau kapas yang digunakan sebagai menyangga fase diam bagian bawah kolom. Setelah kolom siap maka bubur silikagel dimasukkan secara perlahan-lahan menggunakan pipet tetes sambil kran bagian bawah kolom dibuka secara perlahan-lahan. Pengisian fase diam diusahakan agar merata pada setiap permukaan kolom. Fase diam diisi ke dalam kolom sampai tanda batas yang diinginkan (kira-kira $5 \mathrm{~cm}$ di bawah ujung kolom bagian atas). Kolom dielusi menggunakan fase geraknya selama 5-6 jam agar kemampatan kolom homogen.

\section{Pemasukan dan Elusi Sampel}

Setelah kolom homogen, maka permukaan fase gerak diturunkan dengan jalan mengeluarkannya melalui keran sampai permukaan fase gerak sedikit di atas permukaan fase diam. Pada saat itu sampel dimasukkan ke dalam kolom secara merata di atas permukaan fase diam, lalu ditambahi fase gerak sambil keran dibuka pelan-pelan. Kecepatan alir fase gerak dalam kolom diatur kira-kira $1 \mathrm{~mL} / 5$ menit. Eluat ditampung setiap $5 \mathrm{~mL}$ pada botol kecil yang sudah dipersiapkan. Elusi kolom dihentikan jika diperkirakan semua komponen sudah keluar dari kolom.

\section{Penggabungan Hasil Kolom}

Eluat pada masing-masing botol diuji komponennya dengan cara KLT (kromatografi lapis tipis) menggunakan fase diam silikagel $\mathrm{GF}_{254}$ dengan eluen yang sesuai seperti fase gerak pada kolom. Setiap botol eluat ditotolkan pada bagian tepi pelat KLT kemudian dielusi dalam chamber kromatografi. Elusi dihentikan sampai eluen mencapai tanda batas, lalu pelat KLT dikeringkan dengan dianginanginkan dan dideteksi nodanya menggunakan sinar lampu ultra violet atau disemprot dengan reagen pewarna. Setiap botol eluat yang menunjukkan pola noda yang sama dapat digabungkan menjadi satu fraksi, sehingga diperoleh beberapa fraksi. Setiap fraksi yang diperoleh, diuji aktivitas penurun kadar glukosa darah. Fraksi yang menunjukkan aktivitas yang terbaik selanjutnya dilakukan pemurnian.

\section{Perlakuan terhadap tikus}

Penelitian ini mengunakan 40 ekor tikus putih jantan (Rattus novergicus) berumur 3-4 bulan dengan bobot badan 150-200 g. Sebelum digunakan semua tikus diadaptasi selama dua minggu untuk menyesuaikan lingkungan, mengontrol kesehatan, bobot badan serta menyeragamkan makanannya. Tikus dikelompokkan menjadi delapan perlakuan dengan masing-masing perlakuan terdiri dari lima ekor, kemudian ditempatkan dalam kandang terpisah dilengkapi dengan tempat pakan dan minum. Pakan yang diberikan adalah konsetrat dan air minum ad libitum hingga akhir penelitian. 
Menjelang pemberian perlakuan semua tikus dipuasakan terlebih dahulu selama 24 jam. Pada hari ke minus satu (1), dilakukan pengukuran bobot badan terlebih dahulu dan dilanjutkan dengan menginjeksikan STZ sebanyak satu kali secara intraperitoneal dengan dosis 45 $\mathrm{mg} / \mathrm{kg}$ bb. STZ diberikan pada semua perlakuan kecuali tikus kontrol negatif. Pada hari ke-0 saat tikus dipastikan dalam kondisi hiperglikemik dan adanya penurunan bobot badan, penelitian dilanjutkan dengan pemberian perlakuan. Masing-masing pada perlakuan ekstrak etanol buah pare diberikan ekstrak buah pare dan pada perlakuan F1, F2, F3, F4, dan F5 diberikan hasil fraksi kromotografi buah pare berupa fraksi 1 sampai fraksi 5 . Pemberian ektrak etanol dan fraksi buah pare dilakukan secara sonde lambung dengan dosis $50 \mathrm{mg} / \mathrm{kg}$ bb.

\section{Pengukuran Berat Badan}

Pengukuran berat badan dilakukan sesuai waktu pengamatan mulai dari hari ke $-1,0,4,11$, dan 18. Pengukuran bobot badan dilakukan dengan menggunakan timbangan elektronik dan hasil yang didapatkan diukur dalam satuan gram.

\section{Pemeriksaan Kadar Glukosa Darah}

Kadar glukosa diukur pada hari ke-0, pengukuran glukosa darah pada penelitian ini hanya untuk mengkonfirmasi kondisi hiperglikemik setelah pemberian STZ. Pengukuran kadar glukosa darah mengunakan Gluko-Dr® test meter.

Rancangan penelitian dan analisis data

Rancangan penelitian yang digunakan adalah rancangan acak lengkap (RAL) pola Split in Time (Pola berjenjang). Data bobot badan yang diperoleh selanjutnya dianalisis dengan analisis varian. Uji lanjutan yang digunakan untuk melihat perbedaan yang nyata antara perlakuan adalah uji rata-rata Duncan. Perhitungan statistik dilakukan dengan bantuan piranti SPSS 20,0 for Window.

\section{HASIL DAN PEMBAHASAN}

Peningkatan bobot badan diperoleh dengan pemberian fraksi buah pare melalui proses kromatografi lapis tipis. Hasil kromatografi lapis tipis dari partisi $\mathrm{N}$ heksan diperoleh 5 fraksi. Kemudian diberikan pada tikus yang telah diberikan zat diabetogen streptozotosin. Hasil pengamatan dan selisih bobot badan setelah pemberian fraksi buah pare masing-masing dapat dilihat pada Tabel 1 dan 2.

Tabel 1. Rerata Bobot badan Tikus Putih Jantan Hari ke -1 Sampai Hari Ke-18

\begin{tabular}{llllll}
\hline \multirow{2}{*}{ Perlakuan } & \multicolumn{5}{c}{ Rata-rata Bobot badan (g) Heri Ke- } \\
\cline { 2 - 6 } & \multicolumn{1}{c}{$\mathbf{- 1}$} & $\mathbf{0}$ & $\mathbf{4}$ & \multicolumn{1}{c}{$\mathbf{1 1}$} & \multicolumn{1}{c}{$\mathbf{1 8}$} \\
\hline Kontrol Positif & $134,20 \pm 13,57$ & $137,40 \pm 13,50$ & $145,33 \pm 11.24$ & $159,00 \pm 14,0$ & $171,00 \pm 12,49$ \\
Kontrol Negatif & $119,80 \pm 14,52$ & $126,40 \pm 13,24$ & $135,60 \pm 10,45$ & $155,20 \pm 9,09$ & $165,00 \pm 8,34$ \\
Ekstrak etanol pare & $139,00 \pm 17,46$ & $131,20 \pm 22,17$ & $145,60 \pm 13,35$ & $150,80 \pm 13,21$ & $156,60 \pm 20,37$ \\
F1 & $120,40 \pm 17,28$ & $129,80 \pm 27,45$ & $149,00 \pm 19,97$ & $155,20 \pm 28,75$ & $162,40 \pm 32,44$ \\
F2 & $132,80 \pm 10,35$ & $134,00 \pm 12,06$ & $137,60 \pm 12,76$ & $154,40 \pm 9,90$ & $161,80 \pm 10,92$ \\
F3 & $124,00 \pm 13,36$ & $124,20 \pm 20,71$ & $129,20 \pm 19,76$ & $149,40 \pm 20,59$ & $156,20 \pm 21,69$ \\
F4 & $119,00 \pm 18,68$ & $134,80 \pm 4,97$ & $138,40 \pm 11,97$ & $151,00 \pm 17,62$ & $154,60 \pm 26,80$ \\
F5 & $124,60 \pm 8,38$ & $129,40 \pm 12,97$ & $139,00 \pm 14,14$ & $153,80 \pm 14,77$ & $160,20 \pm 15,20$ \\
\hline
\end{tabular}

Keterangan: kontrol positif: injeksi streptozotocin, kontrol negatif: tanpa injeksi streptozotocin ekstrak etanol pare: injeksi streptozotozin dan ekstrak pare, F1: injeksi streptozotozin dan fraksi 1, F2: injeksi streptozotozin dan fraksi 2, F3: injeksi streptozotozin dan fraksi 3, F4: injeksi streptozotozin dan fraksi 4, F5: injeksi streptozotozin dan fraksi 5. 
Tabel 2. Rerata selisih bobot badan tikus putih setelah pemberian STZ (hari ke- 0) sampai setelah pemberian fraksi buah pare (hari ke 4-18).

\begin{tabular}{ccccc}
\hline Perlakuan & \multicolumn{4}{c}{ Rata-Rata Selisih Pertambahan Bobot Badan (Gram) } \\
\cline { 2 - 5 } & $\mathbf{0}$ & $\mathbf{4}$ & $\mathbf{1 1}$ & $\mathbf{1 8}$ \\
\hline Kontrol Positif & $3,20 \pm 6,49^{\mathbf{a}}$ & $16,67 \pm 2,51^{\mathbf{b}}$ & $30,33 \pm 6,11^{\mathbf{b}}$ & $42,33 \pm 2,30^{\mathbf{b}}$ \\
Kontrol Negatif & $6,60 \pm 3,28^{\mathbf{a}}$ & $15,80 \pm 4,60^{\mathbf{b}}$ & $35,40 \pm 13,40^{\mathbf{b}}$ & $45,20 \pm 8,25^{\mathbf{b}}$ \\
Ekstrak Etanol Pare & $-7,80 \pm 17,42^{\mathrm{a}}$ & $6,60 \pm 15,22^{\mathbf{a}}$ & $11,80 \pm 15,22^{\mathbf{b}}$ & $17,60 \pm 23,12^{\mathbf{b}}$ \\
F1 & $9,40 \pm 19,07^{\mathbf{a}}$ & $28,60 \pm 13,16^{\mathbf{b}}$ & $34,80 \pm 21,91^{\mathbf{b}}$ & $42,00 \pm 27,32^{\mathbf{b}}$ \\
F2 & $1,20 \pm 4,97^{\mathrm{a}}$ & $4,80 \pm 11,88^{\mathbf{a}}$ & $21,60 \pm 11,82^{\mathbf{b}}$ & $29,00 \pm 13,92^{\mathbf{b}}$ \\
F3 & $0,20 \pm 23,43^{\mathbf{a}}$ & $5,20 \pm 15,32^{\mathbf{a}}$ & $25,40 \pm 17,44^{\mathbf{b}}$ & $32,20 \pm 20,32^{\mathbf{b}}$ \\
F4 & $15,80 \pm 14,70^{\mathrm{a}}$ & $19,40 \pm 7,23^{\mathbf{a}}$ & $32,00 \pm 3,39^{\mathbf{b}}$ & $35,60 \pm 10,47^{\mathbf{b}}$ \\
F5 & $4,80 \pm 8,01^{\mathrm{a}}$ & $14,40 \pm 13,29^{\mathbf{b}}$ & $29,20 \pm 14,11^{\mathbf{b}}$ & $35,60 \pm 19,10^{\mathbf{b}}$ \\
\hline
\end{tabular}

Keterangan: Angka yang diikuti huruf superscript (a,b,c) yang sama kearah kolom menunjukkan tidak berbeda nyata $(\mathrm{P}>0,05)$. Sedangkan angka dengan huruf yang berbeda pada kolom yang sama menunjukkan nilai yang berbeda nyata $(\mathrm{P}<0,05)$.

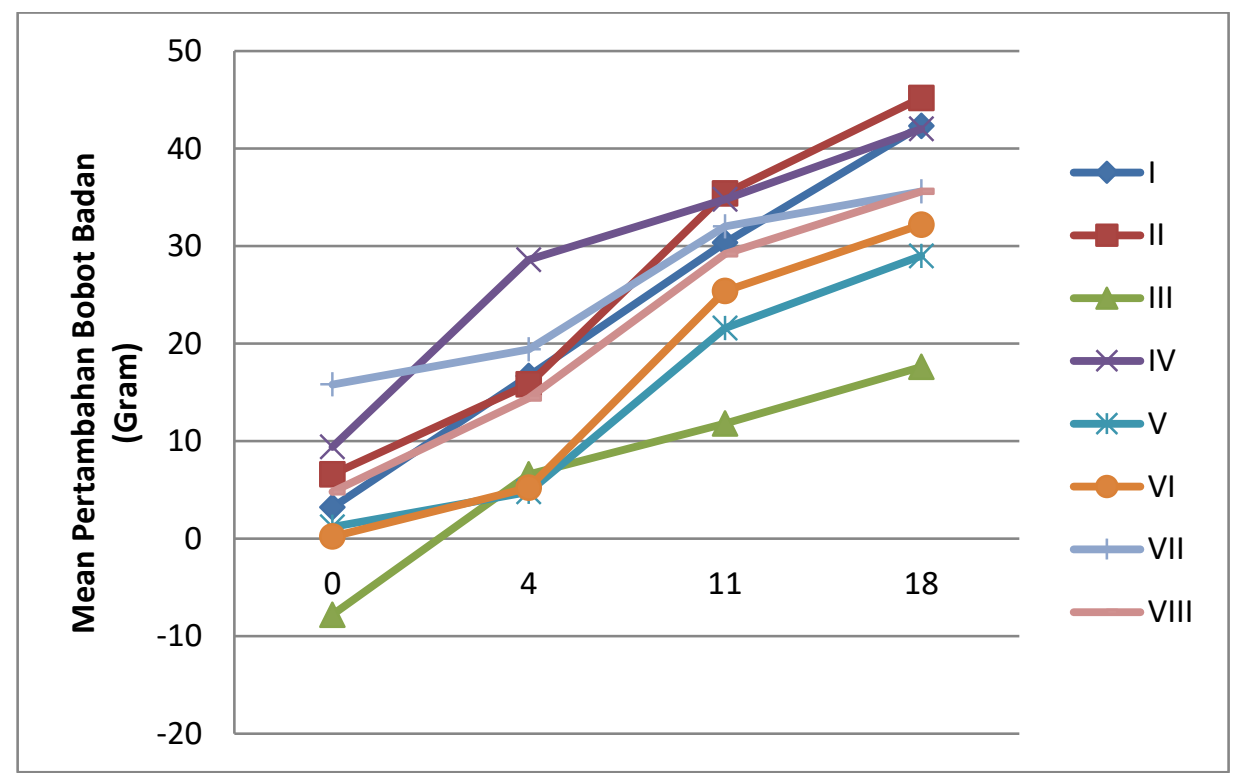

Gambar 1. Grafik rata-rata selisih bobot badan tikus putih hari ke-0 sampai heri ke-18

Keterangan: I: kontrol positif, II: kontrol negatif, III: ekstrak etanol buah pare, IV: fraksi 1 buah pare, V: fraksi 2 buah pare, VI: fraksi 3 buah pare, VII: fraksi 4 buah pare, VIII: fraksi 5 buah pare.

Rerata berat badan tikus masing kelompok setelah pemberian perlakuan fraksi buah pare mengalami peningkatan berbeda-beda sesuai waktu pengamatannya masing-masing. Dihari pengamatan ke-0 terjadi penurunan berat badan yang sangat nyata $(\mathrm{P}<0,01)$ sebesar $-7,80 \pm 17,42$ pada kelompok ekstrak etanol buah pare dibandingkan dengan kelompok perlakuan lainnya. Pada hari pengamatan ke-4 peningkatan berat badan yang sangat nyata $(\mathrm{P}<0,01)$ dijumpai pada perlakuan $\mathrm{F} 1$ dan perlakuan F5 masing-masing 28,60 $\pm 13,16$

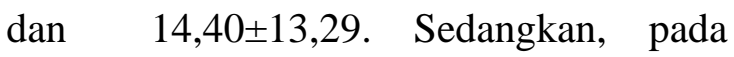
perlakuan lainya baru menunjukkan peningkatan berat badan sangat nyata $(\mathrm{P}<0,01)$ pada hari ke-11 pengamatan yaitu pada perlakuan $\mathrm{F} 2, \mathrm{~F} 3$ dan $\mathrm{F} 4$ dengan masing-masing $21,60 \pm 11,82,25,40 \pm 17,44$ dan $32,00 \pm 3,39$.

Hasil penelitian menunjukkan bahwa bobot badan tikus putih (Rattus norvegicus) hari ke minus satu (-1) pada perlakuan kontrol positif, kontrol negatif, ekstrak etanol pare, F1, F2, F3, F4, dan F5 diketahui masih dalam keadaan normal dan 
belum terjadi perubahan bobot badan. Penurunan bobot badan yang sangat nyata $(\mathrm{P}<0,01)$ dibandingkan dengan perlakuan lainnya terjadi di hari ke-0 pada perlakuan ekstrak etanol buah pare tiga hari setelah pemberian streptozotosin. Penurunan bobot badan terjadi pada saat tikus dalam kondisi hiperglikemia.

Kerusakan pada sel $\beta$ pankreas dikarenakan STZ mengandung suatu senyawa glucosamine nitrosourea seperti agen alkylating lainya yang dapat menimbulkan toksik. STZ sebagai penyebab terjadinya DM berkaitan dengan pembentukan radikal bebas diantaranya $\mathrm{NO}, \mathrm{O}_{2}$, dan $\mathrm{H}_{2} \mathrm{O}_{2}$ yang dapat menyebabkan fermentasi DNA sel akibat sitotxoksik STZ. Penurunan bobot badan pada kelompok ekstrak etanol pare disebabkan oleh terhambatnya kerja dari hormon insulin dimana glukosa tidak diperantarai ke dalam sel tubuh (Izumi et al., 200). Hal ini mendorong terjadinya pemecahan cadangan energi melalui proses glikogenolisis dan lipolisis yang berlangsung terus menerus. Hingga pada akhirnya menyebabkan massa otot dan jaringan lemak berkurang dan berefek pada penurunan bobot badan (Steyn et al., 2004).

Hal berbeda terjadi pada perlakuan kontrol positif, F1, F2, F3, F4, dan F5, dihari yang sama tidak mengalami penurunan bobot badan walaupun telah diberikan streptozotosin. Ini menunjukkan peran streptozotosin pada perlakuan tidak sampai merusak sel $\beta$ pankreas. Respon tikus terhadap pemberian STZ untuk menurunkan bobot badan berbeda-beda. Hal ini disebabkan akibat perbedaan kepekaan dan tingkat kondisi stress dari masing-masing individu tikus. Selain itu, pengaruh induksi STZ dosis rendah dalam satu kali pemberian selama penelitian juga menentukan perubahan bobot badan hewan coba. Menurut Erwin et al (2012), untuk menghasilkan kondisi DM yang kronis pada hewan coba perlu dilakukan induksi dosis rendah STZ secara berulang sehingga presentase nekrosis sel beta langerhans pangkreas meningkat.
Peningkatan bobot badan terjadi dihari ke- 4 pada perlakuan yang diberikan fraksi buah pare. Peningkatan yang sangat nyata $(\mathrm{P}<0,01)$ terjadi pada pemberian fraksi 1 dan fraksi 5 dibanding dengan pemberian fraksi lainya. Hasil perlakuan menunjukkan fraksi 1 dan fraksi 5 paling cepat memberikan reaksi dibandingkan fraksi yang lain (Gambar 1). Peningkatan bobot badan pada fraksi lain baru terjadi dihari ke-11 yaitu pada pemberian fraksi 2 , fraksi 3 dan fraksi 4. Peningkatan ini terjadi sangat nyata $(\mathrm{P}<0,01)$ dibandingkan fraksi lainya. Kontrol positif dan kontrol negatif juga menunjukkan peningkatan bobot badan yang tidak berbeda nyata $(\mathrm{P}>0.05)$ dari awal hari pengamatan sampai hari terahir pengamatan.

Estrak buah pare juga mampu meningkatkan bobot badan pada hari ke-4 dengan pemberian dosis takaran yang sama dengan pemberian fraksi buah pare sebesar $50 \mathrm{mg} / \mathrm{kg}$ bb. Ini menunjukkan bahwa estrak buah pare memiliki sifat kelarutan nonpolar yang berpotensi menurunkan kadar glukosa darah, dan mempunyai efek yang sama dengan senyawa buah pare yang dipartisi dengan larutan N-Heksana. Perbedaan respon peningkatan bobot badan dari kedua perlakuan ini terletak pada kandungan senyawa tungal fraksi 1 dan 5 dipengaruhi golongan senyawa tritepenoid atau steroid yang kuat. Sehingga peningkatan bobot badan pada pemberian kedua fraksi ini memberikan hasil yang lebih signifikan.

Proses kromatografi lapis tipis bertujuan untuk memperoleh senyawa tunggal hasil penampungan eluen dari kromatografi kolom. Untuk setiap eluen yang digunakan pada proses di atas menghasilkan satu noda, maka senyawa tersebut sudah relatif murni dan dapat dikelompokkan dalam satu fraksi (Juliana et al., 2010). Kelima fraksi yang dihasilkan mampu menunjukkan peningkatan bobot badan pada tikus yang sebelumnya diinduksi STZ. Pemberian senyawa tunggal murni dalam ke lima fraksi ini diketahui memiliki aktifitas antihiperglikemia 
terhadap hewan coba. Dalam senyawa ini mengandung komponen sulfonylurea yang diyakini sebagai obat anti diabetes paling tua dan banyak dipakai (Suharmiati, 2003). Sulfonylurea bekerja dengan menstimulasi sel $\beta$ pangkreas tubuh untuk memproduksi insulin lebih banyak. Selain itu, dalam buah pare mengandung beberapa senyawa utama seperti flavonoid, saponin, charantin, polifenol yang juga memiliki fungsi yang sama seperti obat jenis sulfonylurea (Yuda et al., 2013).

Dalam buah pare juga mengandung antioksidan glikosida yang dapat menangkal radikal bebas akibat pemberian senyawa STZ pada hewan coba. Prinsip kerja antioksidan ini adalah memperbaiki secara bertahap jaringan-jaringan yang rusak pada sel $\beta$ pangkreas agar bisa memproduksi insulin kembali. Dengan normalnya produksi insulin akan membantu sel tubuh untuk kembali memperoleh energi (Yulinta, 2013). Glukosa dapat disimpan kembali dalam otot dan hati dalam bentuk glikogen dan bobot badan tikus putih dapat kembali normal bahkan meningkat. Peningkatan bobot badan tikus terjadi karena senyawa aktif fraksi buah pare dapat meningkatkan pengambilan glukosa dari darah ke dalam sel otot, adiposa, dan sel-sel lainnya. Setelah diangkut glukosa dapat diubah menjadi trigliserida (lemak) di sel hati dan sel adiposa atau menjadi glikogen di sel otot dan hati yang dapat digunakan sebagai cadangan energi. Diketahui dengan bertambahnya lemak dan glikogen akan mempengaruhi penambahan bobot badan.

\section{Simpulan}

\section{SIMPULAN}

Fraksi kromatografi lapis tipis partisi $\mathrm{N}-\mathrm{Heksan}$ buah pare pada fraksi 1 dan fraksi 5 dapat meningkatkan bobot badan tikus putih lebih cepat dibandingkan fraksi 2, fraksi 3 dan fraksi 4.

\section{Saran}

Perlu dilakukan penelitian lanjutan mengenai efektifitas fraksi kromotografi ekstrak buah pare (Momordica charantia) pada tikus putih jantan dengan pengaruhnya terhadap histopatologi pada sel-sel beta langerhans pankreas.

\section{UCAPAN TERIMAKASIH}

Penulis mengucapkan terima kasih kepada Direktorat Penelitian dan Pengabdian kepada Masyarakat, Direktorat Jendral Pendidikan dan Kebudayaan Republik Indonesia atas bantuan dana penelitian melalui Lembaga Penelitian dan Pengabdian Masyarakat Universitas Udayana (LPPM- UNUD), dengan kontrak No: 104.18/UN 14.2/PNL.01.03.00/2014.

\section{DAFTAR PUSTAKA}

Abeeleh MA, Ismail ZB, Alzaben KR, Abu-Halaweh SA, El-Essa MK, Abuabeeleh J. 2009. Induction of diabetic mellitus in rats using intraperitoneal streptozotocin: A comperison between two strains of rats. Eur. J. Sci. Res. 32(3): 398-402.

Bawa IGA. 2009. Isolasi dan identifikasi golongan senyawa toksik dari daging buah pare (Momordica charantia L.). J. Kimia. 3(2): 117-124.

Kendran AAS, Sudisma IGN, Sulabda IN, Gorda IW, Anggreni LD, Loekali BM. 2013. Kadar glukosa darah anjing kintamani. Bul. Vet. Udayana. 5(2): 7986.

Erwin, Etriwati, Rusli. 2012. Mencit (Mus musculus) Galur BALB-C yang Diinduksikan Streptozotosin Berulang Sebagai Hewan Model Diabetes Mellitus. JKH. 6(1): 47-50.

Hernawati. 2009. Potensi buah pare (Momordicha charantia L.) sebagai herbal antifertilitas. FPMIPA Universitas Pendidikan Indonesia. Bandung.

Izumi K, Yamada M, Matsukawa and Zorummski CF. 2003. Effect of insuline on long-term potentiation in hippocampal slices from diabetic rats. J. Diabetologia. 46: 1007-1012.

Juliana VA, Aisyah S, Mustapha I. 2010. Isolasi dan karakteristik senyawa turunan terpenoid dari fraksi n-Heksan 
Momordicha charantia L. J. Sains Teknol. Kimia. 1(1): 88-93.

McAnuff MA, Omaruyi FO, Marriso and Asemota HN. 2003. Hepatic fungtion enzymes and lipid peroxidation in streptozotocin-induce diabetic rats feb bitter yam (Diascorea polygonoides) streroidal sapogenin extract. Diabetologia Croatia. 23: 1-7.

Nugroho AE. 2006. Hewan percobaan Diabetes Mellitus: patologi dan mekanisme aksi diabetogenik. Biodiversitas. 7(4): 378-382.

Pasaribu F, Sitorus P, Bahri S. 2012. Uji ekstrak etanol kulit buah manggis (garcinia mangostana 1.) terhadap penurunan kadar glukosa darah. $J$. Pharmaceutics Pharmacol. 1(1): 1-2.

Steyn NP, Mann J, Bennett PH, Temple N, Zimmet P, Tuomilehto J, Lindstro J and Louheranta A. 2004. Diet, nutrition and the prevention of type 2 diabetes. Pub. Health Nutrit. 7(1A): 147-165.

Suharmiati. 2003. Pengujian Bioaktifitas Antidiabetes Millitus Tumbuhan Obat. Badan Penelitian Pengembangan kesehatan. Pusat Penelitiaan dan pengembangan pelayanan dan teknologi kesehatan. Surabaya: Depertemen Kesehatan RI.

Suartha IN, Swantara IMD, Rita WS. 2016. Ekstrak etanol dan fraksi heksan buah pare (Momordica charantia) sebagai penurun kadar glukosa darah tikus diabetes. J. Vet. 17(1): 30-36.

Yuda IKA, Anthara MS, Dharmayudha AAGO. 2013. Identifikasi golongan senyawa kimia ekstrak etanol buah pare (Momordica charantia) dan pengaruhnya terhadap penurunan kadar glukosa darah tikus putih jantan (Rattus novergicus) yang diinduksi aloksan. Bul. Vet. Udayana. 5(2): 87-95.

Yuliana, Widarsa T, Wiranatha G. 2013. Pemberian ekstrak methanol daun paliasa menurunkan kadar glukosa darah tikus hiperglikemik. J. Vet. 14(4): 495-500.

Yulinta NMR, Tono PG, Kardena IM. 2013. Efek toksisitas ekstrak daun sirih merah terhadap gambaran mikroskopis ginjal tikus putih diabetik yang diinduksi aloksan. Bul. Vet. Udayana. 5(2): 114-121. 